\title{
Potential benefits from the adoption of new groundnut varieties in northern Vietnam
}

\section{An ex ante assessment}

\author{
Pratap S. Birthal, Tru'ơng Thi Minh, Nguyen \\ Thi Chinh, Đào Thé Anh, Shyam N. Nigam, \\ Pham Thi Vuong, Nguyen Thien Luong and \\ Dong Hong Tham
}

\begin{abstract}
Enabled by land reforms and fuelled by technological change, agricultural production in Vietnam grew tremendously after the mid-1980s. Focusing on groundnut, an export-oriented cash and food crop, this paper provides estimates of potential benefits from the adoption of improved varieties in northern Vietnam. At farm level, switching over to improved varieties generates additional revenue of VND1.8 to 3.9 million per hectare (US\$1 is equivalent to about VND15,969). The aggregate benefits for northern Vietnam are huge. With the groundnut area remaining unchanged, the annual value of benefits from the adoption of improved varieties in 80\% of the area by 2020 will be VND571,691 million (US $\$ 35.8$ million) at a real discount rate of $5 \%$. These benefits will be $14 \%$ larger if the groundnut area continues to expand at the rate achieved in the recent past.
\end{abstract}

Keywords: groundnut; improved varieties; potential impact; Vietnam

Pratap S. Birthal (corresponding author) is with the National Centre for Agricultural Economics and Policy Research (NCAP), Pusa, New Delhi 110 012, India. E-mail: psbirthal@ncap.res.in. Truóng Thi Minh (e-mail:truongthiminh2001@yahoo.com), Nguyen Thi Chinh (ntchinhlrdc@yahoo.com.vn), Đào Thé Anh (daotheanh@gmail.com), Pham Thi Vuong (tvuong@hn.vnn.vn) and Dong Hong Tham (tham_lrdc@yahoo.com.vn) are with the Vietnam Academy of Agricultural Sciences (VAAS), Thanh Tri, Hanoi, Vietnam. Shyam N. Nigam is with the International Crops Research Institute for the Semi-Arid Tropics (ICRISAT), Patancheru 502 324, Andhra Pradesh, India.

E-mail: s.nigam@cgiar.org. Nguyen Thien Luong is with the Ministry of Agriculture and Rural Development, Government of Vietnam. E-mail: luongnt.khon@mard.gov.vn.

Consistent with the theory of economic development, the share of agriculture in the gross domestic product (GDP) of Vietnam declined to $17 \%$ in 2009 from 35\% in 1986 (GoV, various years), yet fostering rapid growth in agriculture and rural development remains an important policy concern. The importance of agriculture transcends its income contribution. More than $70 \%$ of Vietnam's population lives in rural areas, and a majority of them depend on agriculture and allied activities for their livelihood. The agricultural sector engages $48 \%$ of the country's total labour force. However, agriculture is primarily small-scale - the average size of landholding is 0.54 hectares, and $69 \%$ of the total holdings are of under 0.5 hectares (Tisdell, 2010). Poverty is more prevalent 
among the rural population. Close to $19 \%$ of the rural population is poor, compared with an urban poverty rate of $3.3 \%(\mathrm{GoV}, 2010)$.

The Government of Vietnam $(\mathrm{GoV})$ initiated a major programme of economic renovation known as doi moi in 1986, which, among other things, emphasized the decollectivization of agriculture and reallocation of land to cultivators so as to provide them with greater autonomy in land use and crop choice. This process of land reforms was accompanied by gradual liberalization of the domestic markets, external trade and financial sector so as to facilitate a smooth transition from a state-controlled production system to a marketed-oriented production system. Agricultural investment, as a proportion of the agricultural gross domestic product (AgGDP), increased from a meagre $3 \%$ in the early 1990 s to $20 \%$ in the late 1990 s (GoV, various years), but declined to around 15\% later on. Moreover, agricultural research was increasingly recognized as an important catalyst in the process of agricultural development (Che et al, 2006), and the share of expenditure on agricultural research in AgGDP increased from a mere $0.08 \%$ in 1996 to $0.17 \%$ in 2002 (Stads and Nguyen, 2006).

Vietnam's agricultural sector has grown remarkably since the initiation of doi moi. During the period 19902009 , the sector grew at an annual rate of over $4 \%$, which is comparable with the agricultural growth in China, and is of course much higher than the agricultural growth in many other Asian countries. Production of rice increased from 10 million tons in 1975 to 19 million tons in 1990, and further to 39 million tons in 2009 (FAOSTAT, undated). There was also a substantial increase in the production of maize, fruits, vegetables, and industrial crops such as tea, coffee, rubber, sugar cane, soybean and groundnut. The tremendous increase in agricultural production turned Vietnam from a net importer of food (until the late 1980s) to a net exporter of many agricultural commodities such as rice, coffee and groundnut. For instance, Vietnam exported on average 4.2 million tons of rice a year during 2001-08. Rapid growth in agriculture was accompanied by a significant decline in rural poverty, from 66\% in 1993 to 19\% in 2008 (GoV, various years). This revolutionary progress in agriculture and poverty reduction is attributed to the changes in organization of agricultural production, enabling policies and technological change (Que and Goletti, 2001; Che et al, 2006; Linh, 2009).

Groundnut is an important exported-oriented crop in Vietnam. Until 1999, groundnut contributed 5-10\% to the country's agricultural exports and ranked amongst the top five agricultural export commodities (FAOSTAT, undated). During the 1980s and 90s, Vietnam exported around $40 \%$ of its total groundnut output - which, however, declined to $17 \%$ during the 2000s (FAOSTAT). ${ }^{1}$ Since the mid-1980s, groundnut production in Vietnam has been growing at an annual rate of over $4.5 \%$. This growth was fuelled by technological change, in terms of adoption of new varieties and improved cultivation practices, particularly in northern Vietnam. In this paper, we have evaluated potential benefits from the adoption of improved groundnut varieties in northern Vietnam. The paper is organized into five sections. The next section presents regional trends in area, production and yield of groundnut in Vietnam. The third section discusses methods and data used for estimating benefits from the adoption of new groundnut varieties; and the results are discussed in the fourth section. Concluding remarks are made in the last section.

\section{Groundnut production in Vietnam}

Groundnut in Vietnam is cultivated on 250,000 hectares of land - equivalent to $4 \%$ of the total area under annual crops. Although the area under groundnut cultivation has not expanded much in the past two decades, its production has grown tremendously. Between 1986-88 and 2007-09 the total production of groundnut-in-shell increased 2.4 times, from 219,000 tons to 522,000 tons, at an annual rate of over $4.5 \%$ (Table 1 ). This growth was driven by yield improvements. Groundnut yield more than doubled, from 0.95 ton/ha in 1986-88 to 2.06 ton/ha in $2007-09$, at an annual rate of $3.8 \%$. Yield increased rapidly during 1996-2009, but output growth decelerated.

The landscape of groundnut production also underwent a significant shift after the mid-1990s from the south to the north of Vietnam. Southern Vietnam, which used to account for more than half of the total groundnut area as well as production until the mid-1990s, witnessed a significant decline in the groundnut area. Growth in production decelerated to $1.1 \%$ during 1996-2009, from $6.5 \%$ during the first decade of doi moi. Yield growth also decelerated, but continued to be the main force behind output growth. On the other hand, in northern Vietnam, area and production of groundnut increased at an accelerated rate. The share of northern Vietnam in the total groundnut area increased to $62 \%$ in 2007-09 from $47 \%$ in the mid-1990s; and its contribution to total production grew from $41 \%$ to 59\%. During 1996-2009, groundnut production in northern Vietnam grew at an annual rate of $6.5 \%$ - much higher than the growth during the first decade of doi moi. Yield increases were the main source of output growth.

Groundnut yield, however, is higher in the south where it is grown in the winter-spring season (NovemberMarch) under irrigated conditions after the harvest of rainy season rice. In northern Vietnam, groundnut is grown mainly in the spring season (February-June) under rainfed conditions. In the midlands and sloping areas, groundnut is also cultivated during autumn (JulyNovember). The autumn groundnut is used mainly as seed for the spring season. Evidence from field surveys in Ha Tinh province in the north suggests that the spring groundnut generates $23 \%$ more profit than spring rice (Dao et al, 2009).

Notwithstanding the spatial differences in the production conditions, the robust increase in groundnut yield implies a critical role that improved varieties and cultivation practices have played in enhancing groundnut production. This is substantiated by a significant increase in the expenditure on agricultural research from US\$28 million in 1996 to US\$80 million in 2001 at constant 2000 prices (Stads and Nguyen, 2006), and a rise in the share of total factor productivity in agricultural growth from $11 \%$ during 1990-95 to 29\% during 1995-2000 (Linh, 2009). Farmers continuously replace old varieties with improved ones, and apply manure, chemical fertilizers, pesticides and lime for soil improvement and pest control. A small 
Table 1. Growth in area, production and yield of groundnut in Vietnam, 1986-2009.

\begin{tabular}{|c|c|c|c|c|c|c|c|c|c|}
\hline & \multicolumn{3}{|c|}{ Vietnam } & \multicolumn{3}{|c|}{ South Vietnam } & \multicolumn{3}{|c|}{ North Vietnam } \\
\hline & $\begin{array}{c}\text { Area } \\
\text { (thousand } \\
\text { ha) }\end{array}$ & $\begin{array}{l}\text { Production } \\
\text { (thousand } \\
\text { tons) }\end{array}$ & $\begin{array}{c}\text { Yield } \\
\text { (ton/ha) }\end{array}$ & $\begin{array}{c}\text { Area } \\
\text { (thousand } \\
\text { ha) }\end{array}$ & $\begin{array}{l}\text { Production } \\
\text { (thousand } \\
\text { tons) }\end{array}$ & $\begin{array}{l}\text { Yield } \\
\text { (ton/ha) }\end{array}$ & $\begin{array}{c}\text { Area } \\
\text { (thousand } \\
\text { ha) }\end{array}$ & $\begin{array}{l}\text { Production } \\
\text { (thousand } \\
\text { tons) }\end{array}$ & $\begin{array}{c}\text { Yield } \\
\text { (ton/ha) }\end{array}$ \\
\hline $1986-88$ & 229 & 219 & 0.95 & 121 & 114 & 0.94 & 108 & 105 & 0.97 \\
\hline 1995-97 & 259 & 348 & 1.34 & 133 & 203 & 1.53 & 126 & 145 & 1.15 \\
\hline \multirow[t]{2}{*}{ 2007-09 } & 253 & 522 & 2.06 & 96 & 215 & 2.24 & 157 & 307 & 1.95 \\
\hline & \multicolumn{9}{|c|}{$\%$ annual compound growth rate } \\
\hline 1986-1995 & 0.99 & 4.58 & 3.59 & 1.22 & 6.53 & 5.25 & 0.76 & 1.52 & 0.75 \\
\hline 1996-2009 & -0.10 & 4.03 & 4.01 & -2.39 & 1.08 & 3.55 & 1.72 & 6.49 & 4.69 \\
\hline 1986-2009 & 0.80 & 4.54 & 3.75 & -0.94 & 2.75 & 3.72 & 1.36 & 5.32 & 3.96 \\
\hline
\end{tabular}

Source: GoV (various years).

proportion of farmers also use polythene mulch, which is reported to enhance groundnut yield significantly. Under experimental conditions, Ramakrishna et al (2006) found that groundnut yields from polythene-mulched plots were almost double those from the non-mulched plots.

\section{Analytical approach}

\section{Study location}

Compared with southern Vietnam, northern Vietnam has a more rugged terrain, poor irrigation facilities and infrastructure (roads and markets), underdeveloped institutions (credit and extension), low urbanization and a high incidence of poverty (Minot et al, 2006). It has a monsoon-type climate - hot and wet summers (AprilAugust) and cool, cloudy and moist winters (December-February) (Chuc et al, 2006). Mean annual temperature is $25^{\circ} \mathrm{C}$, ranging from a low of $12^{\circ} \mathrm{C}$ in January to a high of $35^{\circ} \mathrm{C}$ in August. Annual rainfall in the region ranges between 1,100 and 3,000 $\mathrm{mm}$, and most of it $(>75 \%)$ is received from May to September. The length of the growing period varies from 180 to 365 days, implying that there are considerable opportunities for multiple cropping in this region.

About three-quarters of northern Vietnam is uplands (mountains and hills) and the remaining 25\% consists of lowlands. Rice, sweet potato, maize, groundnut, mung bean and soybean are important annual crops here. Tea is the most important industrial crop in this region. Groundnut is grown as a rainfed crop in the uplands, mainly during the spring season, and occupies $5.2 \%$ of the agricultural land. In most provinces in the north, groundnut yield is low ( $\approx 2$ ton/ha), which could be doubled by enhancing the adoption of improved varieties and cultivation practices (Chuc et al, 2006).

The Vietnam Academy of Agricultural Sciences (VAAS), in collaboration with the International Crops Research Institute for the Semi-Arid Tropics (ICRISAT), started promoting new improved varieties and cultivation practices in Nghe An province (now divided in two, Ha Tinh and Nghe An) in northern Vietnam in the late 1990s. Today, Ha Tinh is the second largest producer of groundnut in northern Vietnam, after Nghe An. In this province, groundnut occupies $17 \%$ of the total agricultural land.
Between 1995 and 2009, the groundnut area and production here grew at annual rates of $3.3 \%$ and $7.6 \%$ respectively (Table 2). Improved production technologies were also promoted in Tuyên Quang province where groundnut occupies 7\% of the agricultural land. Groundnut yield in Tuyên Quang is higher than that in Ha Tinh. Area and production of groundnut in Tuyên Quang grew at annual rates of $3 \%$ and $12.2 \%$ respectively during the period 1995-2009.

Tremendous growth in groundnut production in northern Vietnam in general, and Ha Tinh and Tuyên Quang provinces in particular, was on account of the adoption of high-yielding varieties and improved cultivation practices, including application of manure and fertilizer, lime, pesticides and polythene mulching. Application of lime improves yield by $22-29 \%$ and also raises soil $\mathrm{pH}$. Likewise, the use of polythene mulch in winter-sown crop has been reported to provide 30-60\% more yield (Nigam and Gowda, 2005). The old groundnut varieties are now being regularly replaced by the new varieties, following farmer-participatory varietal selection trials and their massive seed production and distribution. Sen Lai and V 79 were the dominant varieties in northern Vietnam until the mid-1990s, but were replaced to a large extent by L 02, QD 12 and LVT in the late 1990s. Since 2000, new improved varieties, such as L 08, MD 7, MD 9, L 12, L 14, L 18, L 20, L 23 and L 26, have been introduced to replace the existing varieties. Farmers, however, preferred L 14 and L 23 because of their higher yield, resistance to foliar diseases and capability to withstand moisture stress. Some farmers still grow Sen Lai, QD 12, V 79 and MD 7.

Table 2. Area, production and yield of groundnut in Ha Tinh and Tuyên Quang provinces, 1995-2009.

\begin{tabular}{lccccccc}
\hline & \multicolumn{2}{c}{$\begin{array}{c}\text { Area } \\
\text { (thousand ha) }\end{array}$} & \multicolumn{2}{c}{$\begin{array}{c}\text { Production } \\
\text { (thousand t) }\end{array}$} & \multicolumn{2}{c}{$\begin{array}{c}\text { Yield } \\
\text { (ton/ha) }\end{array}$} \\
& Ha & Tuyên & \multicolumn{2}{c}{ Ha } & Tuyên & Ha & Tuyên \\
& Tinh & Quang & Tinh & Quang & Tinh & Quang \\
1995-97 & 13.8 & 3.0 & 16.6 & 3.2 & 1,205 & 1.08 \\
$2007-09$ & 20.3 & 4.4 & 41.5 & 11.2 & 2,039 & 2.55 \\
$\begin{array}{l}\text { Annual } \\
\text { growth (\%) }\end{array}$ & 3.3 & 3.0 & 7.6 & 12.2 & 4.1 & 8.9 \\
\hline
\end{tabular}

Source: GoV (various years). 


\section{Data and methodology}

Information needed to assess the impact of improved varieties was compiled from various published and unpublished sources, as well as through personal communication with groundnut experts in Vietnam. Data on farm-level indicators (yield, cost of production, price) were extracted from the survey reports of Dao et al (2009). These surveys were conducted in 2008 in three communes involving 45 farmers in Huong Son district of Ha Tinh province, and in three communes involving 80 farmers in the Chiem Hoa district of Tuyên Quang province.

Average yields and production costs of different varieties estimated with farm-level data were generalized for northern Vietnam, with groundnut area in Ha Tinh and Tuyên Quang provinces as weights. Farm-level impacts from the adoption of improved varieties were scaled up to the level of northern Vietnam using the economic surplus approach, which is widely used to evaluate the impact of technological change on social welfare because of its less restrictive assumptions and minimum data requirement. The approach requires certain assumptions and parameters, which we have derived from the published literature. The aggregate economic impact was assessed considering the rate and time of adoption. Information on current and likely adoption rates of new varieties was gathered through personal communication with experts in groundnut breeding and extension workers. Information on area, production, yield and trade was compiled from various issues of the Statistical Year Book published by the General Statistical Office, Government of Vietnam (GoV, various years). Demand and supply elasticities were taken from Que and Que (2000).

Alston et al (1998) suggested a number of variants of the economic surplus approach considering regional economic structure, trade flows, incentives and taxes. We have estimated economic surplus due to yield improvements using the 'small open-economy' framework. Alston et al (1998, p 226) argue that a small open-economy assumption is often appropriate as most agricultural products are tradable and most countries do not influence international prices significantly. Vietnam has been a net exporter of groundnut - mainly shelled nuts - for a long time. In the 1980s and 1990s, Vietnam exported on average $40 \%$ of its groundnut production. During 2000-2008, this proportion fell to $17 \%$. Note that with the assumption of a small open economy, the benefits from the adoption of improved technologies accrue only to producers.

Figure 1 illustrates changes in the economic surplus due to adoption of an improved technology in the case of a small open economy. ${ }^{2}$ Adoption of a yield-increasing technology shifts the supply curve for groundnut downward from $S_{0}$ to $S_{1}$, while the demand curve is assumed to remain unchanged. The price of groundnut is determined by the world market at $\mathrm{P}_{0}$ and will not change because of an increase in domestic production. Consumer surplus, thus, remains constant, and the entire benefits from the adoption of improved technology accrue to the producers. In this case, the change in producer surplus is equal to the area $a b c d$.

Mathematically, the change in producer surplus can be represented as:

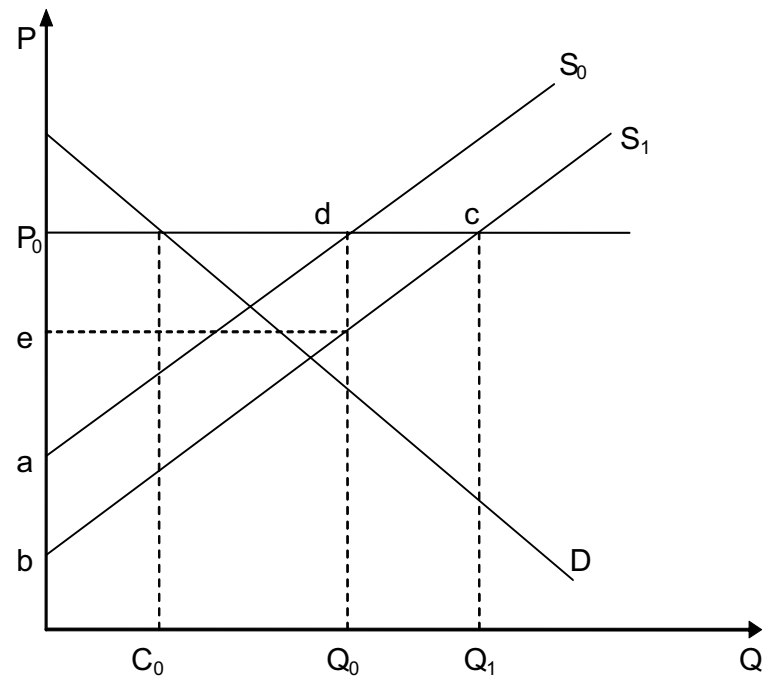

Figure 1. Economic surplus from adoption of improved technology in an open-economy framework.

$$
\Delta P S_{t}=\Delta T S_{t}=P_{0} Q_{0}\left(K_{t}-Z_{t}\right)\left(1+0.5 Z_{t} \eta\right)
$$

where $\triangle P S_{t}$ is the change in producer surplus in year $t$, and $\Delta T S_{t}$ is the change in total surplus in year $t . P_{0}$ is the initial price, $Q_{0}$ is the initial level of production, $Z_{t}$ is the reduction in price in year $t$ as a result of an increase in the supply due to adoption of improved technology, $\eta$ is the absolute value of demand elasticity, and $K_{t}$ is the proportionate supply shift in year $t$ due to adoption of improved technology. The value of $K_{t}$ can be obtained as:

$$
K_{t}=\{[E(Y)] / \varepsilon-[E(C)] /[1+E(Y)]\} \rho A_{t}\left(1-\delta_{t}\right)
$$

where $E(Y)$ is the change in production per hectare, $E(C)$ is the change in variable cost per hectare to achieve the yield change, $\varepsilon$ is the supply elasticity, $\rho$ is success rate or probability that the new variety will achieve the expected yield, $A_{t}$ is the adoption rate in year $t$, and $\delta_{t}$ is the depreciation on the improved variety: that is, the reduction in expected yield in year $t$.

\section{Results and discussion}

\section{Farm-level benefits}

Table 3 presents farm-level impacts of the cultivation of improved groundnut varieties L 23 and L 14 in Ha Tinh and Tuyên Quang provinces. On average, the variety L 23 has a yield advantage of $30 \%$ over the old varieties, and of $12 \%$ over L 14 . The average yield of L 14 is $17 \%$ more than the average yield of the old varieties.

The improved varieties have a significant yield advantage over the old varieties, but their cultivation is more expensive. The per hectare variable costs of producing L 23 and L 14 are $22 \%$ and $12 \%$ more respectively than those for the old varieties. Their significant yield advantage, however, reduces their unit cost of production, and makes their cultivation more lucrative compared with the old varieties. The gross margin from L 23 is $52 \%$ and from L $1430 \%$ more than that from the old varieties. Thus, switching to L 23 generates additional revenue of VND3.9 million/ha, and to 
Table 3. Comparative economics of improved versus local varieties in North Vietnam, 2008.

\begin{tabular}{|c|c|c|c|c|c|c|c|c|c|}
\hline & \multicolumn{3}{|c|}{ Ha Tinh province } & \multicolumn{3}{|c|}{ Tuyên Quang province } & \multicolumn{3}{|c|}{ Northern Vietnam } \\
\hline & L 14 & $L 23$ & Local & $L 14$ & $L 23$ & Local & $L 14$ & $L 23$ & Local \\
\hline \multirow[t]{2}{*}{ Yield (ton/ha) } & 2.31 & 2.66 & 2.00 & 3.06 & 3.18 & 2.57 & 2.46 & 2.76 & 2.11 \\
\hline & $(0.67)$ & $(0.64)$ & $(0.50)$ & $(0.79)$ & $(0.75)$ & $(0.62)$ & $(0.69)$ & $(0.66)$ & $(0.52)$ \\
\hline Variable cost (million VND/ha) & 18.34 & 20.27 & 16.51 & 18.29 & 18.00 & 15.51 & 18.33 & 19.84 & 16.32 \\
\hline Revenue (million VND/ha) & 26.27 & 30.04 & 22.47 & 34.75 & 35.91 & 28.93 & 27.89 & 31.16 & 23.70 \\
\hline Gross margin (million VND/ha) & 7.93 & 9.77 & 5.96 & 16.46 & 17.90 & 13.42 & 9.56 & 11.32 & 7.38 \\
\hline Unit cost (million VND/ton) & 7.92 & 7.63 & 8.27 & 5.98 & 5.67 & 6.04 & 7.46 & 7.20 & 7.75 \\
\hline Price (million VND/t) & 11.35 & 11.30 & 11.26 & 11.35 & 11.30 & 11.26 & 11.35 & 11.30 & 11.26 \\
\hline
\end{tabular}

Note: Figures in parentheses are standard deviations.

Source: Dao et al (2009).

L 14, VND1.8 million/ha. The variability (coefficient of variation) in cross-sectional yield is marginally lower for L 23 than for L 14 and the old local varieties. These findings underscore the comparative advantage in cultivation of L 23 over other varieties.

\section{Aggregate benefits}

The farm-level benefits of the improved varieties were aggregated to the level of northern Vietnam using the economic surplus model with certain assumptions and parameters (Table 4). Changes in yield and variable cost are the most important parameters in aggregation of the benefits. These parameters were estimated from the information presented in Table 3 . The price of groundnut was estimated as the unit value of Vietnam's exports of groundnut-in-shell during the period from 2006-08 (FAOSTAT, undated). The estimated price was US $\$ 712 /$ ton - equivalent to VND11.37 million/ton at an exchange rate of VND15,976 per US\$1.

Information on area cultivated with improved varieties was derived through consultation with groundnut breeders and extension workers. Accordingly, the variety L 14 occupied about $5 \%$ of the total groundnut area in 2006. Variety L 23 was introduced in farmers' fields in the same year. According to expert opinion, by 2020, these varieties will occupy $80 \%$ of the total groundnut area in northern Vietnam (L 14, 30\% and L 23, 50\%). Furthermore, it is assumed that their adoption will follow a sigmoid

Table 4. Values of the parameters used for estimating impact of improved groundnut varieties in northern Vietnam.

\section{Parameter}

Variety L $14 \quad$ Variety L 23

Production quantity, thousand $t$, 2006-08

Price, VND million per $\mathrm{t}, 2006-08$

Yield change per ha $(\%)$

Variable cost change per ha $(\%)$

Adoption rate in 2006

Maximum adoption rate in 2020 (\%)

Time to achieve maximum adoption

Supply elasticity

Demand elasticity

Annual growth in area (\%) during

1986-2009

Discount rate (\%)

\begin{tabular}{cc}
280 & 280 \\
11.37 & 11.37 \\
+16.6 & +30.8 \\
+12.3 & +21.6 \\
5 & 0 \\
30 & 50 \\
$2006-2020$ & $2006-2020$ \\
+0.3307 & +0.3307 \\
-1.3901 & -1.3901 \\
& \\
1.36 & 1.36 \\
$5 \%$ and $8 \%$ & $5 \%$ and $8 \%$ \\
\hline
\end{tabular}

curve to reach their respective ceiling levels in 2020. Groundnut yield in northern Vietnam increased at an accelerated rate, indicating frequent replacement of the old varieties with new ones. Hence, we do not anticipate any depreciation in the yield of new varieties. Further, groundnut area is assumed to follow the same trend as during 1986-2009. The groundnut area during this period grew at an annual rate of $1.36 \%$. Other important parameters used in this analysis are the elasticities of demand and supply, which we adopted from Que and Que (2000).

The stream of benefits needs to be discounted using an appropriate discount rate to find out their net present value (NPV). Finding a suitable discount rate is difficult, however. There is little agreement among economists regarding an appropriate discount rate. In developing countries, it is common to use a discount rate of $10-12 \%$ (Zhuang et al, 2007). Developed countries use a lower discount rate $(3-7 \%)$. In Vietnam, while assessing net benefits of a rodent control project, Palis et al (2004) used a discount rate of $10 \%$. In the past decade, the Central Bank of Vietnam has announced discount rates of $4-11 \%$ with a modal value of $6 \% .{ }^{3}$ Alston et al (1998), however, suggest that when the analysis is conducted using constant prices, the discount rate should be a real rate of interest, which in most situations would fall in the range of 3 to 5\%. For agricultural projects in India, Kula (2004) estimated a discount rate of $5.2 \%$. Alpuerto et al (2009) applied a discount rate of $5 \%$ in their study on ex ante assessment of the benefits of marker-assisted breeding in rice in selected countries of South and South-east Asia. We have estimated NPV using real discount rates of $5 \%$ and $8 \%$.

Estimated benefits from the adoption of improved groundnut varieties are given in Table 5. In a small openexporting economy, the entire benefits from the adoption of improved technologies accrue to producers, and the consumer surplus remains constant as no single country can influence world market prices in a significant manner. Assuming that there is no area expansion under groundnut, the NPV of the cumulative benefits from the adoption of L 14 and L 23 on $30 \%$ and $50 \%$ of the total groundnut area respectively is estimated at VND8,573,373 million or US $\$ 537$ million for the period 2006-2020 at a discount rate of $5 \%$. However, with groundnut area expanding at an annual rate of $1.36 \%$, as in the past two decades, the cumulative value of the benefits increases to 
Table 5. Net present value of benefits (million VND) from adoption of improved groundnut varieties in northern Vietnam, 2006-2020.

\begin{tabular}{|c|c|c|c|c|c|}
\hline \multirow{2}{*}{ Variety } & \multirow{2}{*}{$\begin{array}{c}\text { Adoption } \\
\text { rate }(\%)\end{array}$} & \multicolumn{2}{|c|}{$\begin{array}{l}\text { Without area } \\
\text { expansion } \\
\text { Discount rate }\end{array}$} & \multicolumn{2}{|c|}{$\begin{array}{c}\text { With area } \\
\text { expansion } \\
\text { Discount rate }\end{array}$} \\
\hline & & $5 \%$ & $8 \%$ & $5 \%$ & $8 \%$ \\
\hline L 14 & 30 & $2,984,967$ & $2,399,480$ & $3,326,769$ & $2,660,827$ \\
\hline L 23 & 50 & $5,590,406$ & $4,201,313$ & $6,423,326$ & $4,814,809$ \\
\hline Total & 80 & $8,575,373$ & $6,600,793$ & $9,750,095$ & $7,475,636$ \\
\hline
\end{tabular}

Source: Estimated by the authors.

VND9,750,095 million or US\$610 million. Annually, the benefits from adoption of these varieties will be VND571,691 million (US\$35.8 million) without area expansion and VND650,006 million (US\$40.7 million) with area expansion. These benefits will be $23 \%$ lower at a discount rate of $8 \%$.

If there were no difference in the unit cost of production of improved varieties and local varieties, and no area expansion, by 2020 groundnut production in northern Vietnam would increase to 460,000 tons and average yield would rise to 2.93 tons/ha. Should the area under groundnut continue to expand as in the past, the volume of production would be $12.5 \%$ larger, but the average yield would be $6.5 \%$ less. These findings suggest that there is considerable scope to enhance groundnut production in northern Vietnam through dissemination of improved varieties and cultivation practices.

\section{Conclusions}

Groundnut production systems in Vietnam have undergone a sea change. Fuelled by technological change and supported by agricultural policies, groundnut production grew at an annual rate of $4.5 \%$ during the period 1986-2009. The landscape of groundnut production also started shifting northwards after the mid-1990s, raising its share of total groundnut production from $41 \%$ in 1995-97 to 59\% in 2007-09. Groundnut production in northern Vietnam grew at an accelerated rate, from 1.5\% during 1986-95 to 6.5\% a year during 1996-2009. These trends were the opposite of trends in southern Vietnam where the growth in production was driven by yield, which increased at an annual rate of $4.7 \%$ during $1996-$ 2009 , as against $0.75 \%$ during $1986-95$.

This paper has provided estimates of the potential economic benefits from the adoption of high-yielding groundnut varieties. At farm level, switching to the improved varieties can generate additional revenue of VND1.8 to 3.9 million/ha. Aggregate benefits for northern Vietnam are huge. With no exogenous growth in production, annual present value of benefits from the adoption of improved varieties to $80 \%$ of the total groundnut area by 2020 is estimated at VND571,691 million (US\$35.8 million) at a discount rate of 5\%. With exogenous growth in area, as in the recent past, these benefits will increase by VND78,315 million (US\$4.9 million). The physical production of groundnut in northern Vietnam is expected to be in the range of 460,000 to 520,000 tons by 2020 , with an average yield of 2.74 to $2.93 \mathrm{~kg} / \mathrm{ha}$.

\section{Acknowledgments}

This study was conducted under the aegis of IFAD Grant 954-ICRISAT project. The financial support from IFAD is gratefully acknowledged.

\section{Notes}

1 We tried to ascertain reasons for a substantial decline in the exports of groundnut through discussions with scientists and agricultural economists at the Vietnam Academy of Agricultural Sciences, Hanoi. It emerged that the recent official statistics on groundnut exports are underestimated as huge quantities of groundnut are illegally exported to neighbouring countries.

2 For more details on the graphical representation and mathematical derivations of the economic surplus, see Alston et al (1998, pp 226-228).

3 For more details visit: https://www.cia.gov/library/ publications/the-world-factbook/fields/2207.html.

\section{References}

Alpuerto, V.L.E.B., Norton, G.W., Alwang, J., and Ismail, A.M. (2009), 'Economic impact analysis of marker-assisted breeding for tolerance to salinity and phosphorous deficiency in rice', Review of Agricultural Economics, Vol 31, pp 779-792.

Alston, J.M., Norton, G.W., and Pardey, P.G. (1998), Science Under Scarcity: Principles and Practice for Agricultural Research Evaluation and Priority Setting, CAB International, Wallingford.

Che, T.N., Kompas, T., and Vousden, N. (2006), 'Market reform, incentives and economic development in Vietnamese rice production', Comparative Economic Studies, Vol 48, pp 277-301.

Chuc, N.T., Singh, P., Srinivas, K., Ramakrishna, A., Chinh, N.T., Thang, N.V., Wani, S.P., and Long, T.D. (2006), Yield Gap Analysis of Major Rainfed Crops of Northern Vietnam Using Simulation Modeling, Report No 26, Global Theme on Agroecosystems, International Crops Research Institute for the Semi-Arid Tropics, Patancheru, India.

Dao, T.A., Minh, T.T., and Nga, U.T. (2009), Report on Socioeconomic Survey Under the Project on Harnessing the True Potential of Legumes: Economic and Knowledge Empowerment of Poor Rainfed Farmers in Asia, Vietnam Academy of Agricultural Sciences (VAAS), Hanoi, and International Crops Research Institute for the Semi-Arid Tropics, Patancheru, India.

FAOSTAT (undated), Food and Agriculture Organization, Rome, website: http://faostat.fao.org.

GoV - Government of Vietnam (various years), Statistical Year Book, General Statistical Office, Hanoi.

Kula, E. (2004), 'Estimation of a social rate of interest for India', Journal of Agricultural Economics, Vol 55, pp 91-99.

Linh, V.H. (2009), Vietnam's Agricultural Productivity: A Malmquist Index Approach, Working Paper 0903, Center for Agricultural Policy, Institute of Policy and Strategy for Agriculture, Hanoi.

Minot, N., Epprecht, M., Tram Anh, T.T., and Trung, L.Q. (2006), Income Diversification and Poverty in the Northern Uplands of Vietnam, Research Report 145, International Food Policy Research Institute, Washington, DC.

Nigam, S.N., and Gowda, C.L.L. (2005), 'Vietnam-ICRISAT partnership in groundnut research and development: a success story', in Lieu, P., ed, Studies on the Development of Oil Plants and Vegetable Oils in Vietnam, Oil Plant Institute, Ministry of Industry, Agricultural Publishing House, Ho Chi Minh City. Palis, F.G., Sumalde, Z.M., and Hossain, M. (2004), Assessment of 
Rodent Control Projects in Vietnam: Adoption and Impact, Impact Assessment Series Report No 24, Australian Centre for International Agricultural Research, Canberra.

Que, N.N., and Goletti, F. (2001), Explaining Agricultural Growth in Vietnam, Agrifood Consulting International, Hanoi.

Que, N.T., and Que, N.N. (2000), Effects of Trade Liberalization on Agriculture in Vietnam, Commodity Aspects, Working Paper 52, The CGPRT Centre- Regional Co-ordination Centre for

Research and Development of Coarse Grains, Pulses, Roots and Tuber Crops in the Humid Tropics of Asia and the Pacific, Bogor.

Ramakrishna, A., Tam, H.M., Wani, S.P., and Long, T.D. (2006), 'Effect of mulch on soil temperature, moisture, weed infestation and yield of groundnut in northern Vietnam', Field Crops Research, Vol 95, pp 115-125.

Stads, Gert-Jan, and Nguyen, V.H. (2006), Agricultural Science and Technology Indicators - Vietnam, ASTI Country Brief 33, International Food Policy Research Institute, Washington, DC. Tisdell, C. (2010), Economic Growth and Transition in Vietnam and China and its Consequences for their Agricultural Sectors: Policy and Agricultural Adjustment Issues, Economics, Ecology and the Environment Working Paper 171, University of Queensland, Brisbane.

Zhuang, J., Liang, Z., Lin, T., and De Guzman, F. (2007), Theory and Practice in the Choice of Social Discount Rate for Cost-Benefit Analysis: A Survey, Asian Development Bank, Manila. 